\title{
ZNAČAJ PERCEPCIJE OSOBNE SIGURNOSTI U TURISTIČKOJ DESTINACIJI S ASPEKTA MLADIH TURISTA
}

\author{
Lidija Bagarić \\ Dr. sc., docent, Sveučilište u Rijeci, Fakultet za menadžment u turizmu i ugostiteljstvu, Primorska 42, \\ 51410 Opatija, Hrvatska; e-mail: lidijab@ fthm.hr
}

\section{Mateja Barišić}

Mag. oec., studentica, Sveučilište u Rijeci, Fakultet za menadžment u turizmu i ugostiteljstvu, Primorska 42, 51410 Opatija, Hrvatska; e-mail: ds2427@fthm.hr

\section{Linda Martić Kuran}

Univ. spec. oec., viši predavač, Veleučilište Marko Marulić u Kninu, Petra Krešimira IV 30, Knin, Hrvatska; e-mail:Imartic@veleknin.hr

\section{SAŽETAK}

Suvremeni turizam razvojem transporta i raznih oblika komunikacijske i druge tehnologije pridonosi upoznavanju i zbližavanju razlicitih kultura, što povećava međusobnu toleranciju i pridonosi svjetskom miru, dok su istodobno značajan preduvjet za razvoj turizma mir i sigurnost u destinaciji. Razvoj turizma u interesu je brojnih zemalja radi njegova pozitivnog i multiplicirajućeg utjecaja na gospodarstvo, ali događaju se i velike promjene sa sigurnosnog aspekta u zemljama diljem svijeta, pa sigurnost postaje jedan od najvažnijih kriterija pri odabiru destinacije. Sukladno tome mijenjaju se i obrasci ponašanja turista, pa osobna sigurnost turista, koja proizlazi iz sigurnosne situacije u zemlji, postaje sve značajniji element uspješnog pozicioniranja turističke destinacije. Cilj je rada prikazati stavove mladih inozemnih turista o sigurnosti u destinaciji te njihove percepcije sigurnosnog stanja u Hrvatskoj i zemljama užeg konkurentskog okruženja. Rezultati istraživanja pokazuju da je percepcija sigurnosti značajan element prilikom odabira turističke destinacije, a Hrvatsku se percipira kao iznadprosječno sigurnu zemlju, što su značajni podaci koje bi trebalo više koristiti u promociji Hrvatske kao turističke destinacije.

Ključne riječi: osobna sigurnost, globalna nesigurnost, terorizam, percepcija rizika 


\section{UVOD}

Posljednjih nekoliko desetljeća zanemarivo je kratko vrijeme u smislu cjelokupne svjetske povijesti, no istodobno je obilježeno velikim i značajnim promjenama u smislu komunikacijskog povezivanja i lakše mobilnosti i dostupnosti. Turizam pridonosi promicanju svjetskog mira i tolerancije, ali bez mira i sigurnosti ne može opstati. Određeni oblici nesigurnosti, od kojih je terorizam daleko najupečatljiviji, specifični su za suvremeno doba te se pojavljuju diljem svijeta, u nerazvijenim zemljama, zemljama u razvoju, ali isto tako i u gospodarski razvijenim zemljama, obuhvaćajući čitav niz turističkih destinacija, poput tipičnih odmorišnih destinacija, ali i europskih kulturnih metropola.

Slijedom navedenog, istraživačko pitanje ovog rada je saznati kako mladi turisti reagiraju na pojavu novih sigurnosnih rizika i kakva je njihova percepcija osobne sigurnosti u Hrvatskoj kao turističkoj destinaciji i njezinom konkurentskom okruženju. Stručna literatura, s obzirom na aktualnost tematike, još uvijek ne pokriva navedena i brojna druga pitanja kada je riječ o rizicima, imidžu destinacije i ponašanju turista. Svrha ovog rada je dotaknuti kompleksno pitanje percepcije o sigurnosti u različitim destinacijama iz perspektive turista, istaknuti čimbenike koji utječu na percepciju sigurnosti i analizirati utjecaj percepcije sigurnosti na turističko ponašanje. Cilj rada je ukazati na iznimnu važnost uključivanja elementa sigurnosti u pozicioniranje Hrvatske kao turističke destinacije s obzirom na to da kriterij osobne sigurnosti sve više dobiva na značenju u procesu odabira destinacije. Predmet istraživanja su stavovi mladih inozemnih turista naspram sigurnosti i njihova percepcija sigurnosnog stanja u Hrvatskoj i zemljama užeg konkurentskog okruženja.

\section{TEORIJSKA PODLOGA}

Prema teoriji hijerarhije potreba Abrahama Maslowa (1954), potreba za sigurnošću slijedi odmah nakon osnovnih fizioloških potreba. Uzimajući u obzir globalne trendove, prema godišnjem izvješću Svjetske turističke organizacije za 2017. godinu (UNWTO, 2017:28), globalna zabrinutost po pitanju sigurnosti (engl. safety and security) ${ }^{1}$ kao prepreke putovanju, prvi je od tri prioriteta, uz tehnološku revoluciju i smjer prema održivom razvoju.

\section{1 Globalna nesigurnost i pojava terorizma na vrhuncu razvoja turizma}

Prema Sirakayi i drugima (1997), u prošlosti su se putnici manje zamarali sigurnošću destinacije za odmor kao jednim od faktora privlačenja (engl. pull factors) ${ }^{2}$ te je do 1987. godine sigurnost bila element koji je kontinuirano bio rangiran kao najmanje važan čimbenik pri donošenju odluka o putovanju. Međunarodni turizam smatra se katalizatorom smanjenja napetosti i izgradnje mira (Yu i Chung, 2001:538). Young-Sun Shin ističe značajnu ulogu turizma u doprinosu miru u svijetu. Pritom je odnos između turizma i mira dvostran jer turizam može biti vitalna sila za stvaranje mira,

1 Engleske riječi safety i security sinonimi su koji su na hrvatski prevedeni jednom riječju „sigurnost“ te se u govoru i pisanju razlikuju po tome što safety sadrži emocionalnu komponentu osjećaja sigurnosti, a security stanje sigurnosti. U kontekstu turizma i suvremenih rizika, u stručnoj se literaturi češće koristi izraz safety.

2 Prema Sirakayi i dr. (1997) pull factors ili faktori privlačenja su materijalni i nematerijalni resursi imidža određene destinacije koji omogućuju putnicima realiziranje potreba u određenom turističkom iskustvu. 
ali je turizmu istodobno potreban mir za njegov razvoj i prosperitet (Young-Sun, 2005:415). Kada se sigurnosni incidenti poput rata, terorizma, kriminala i građanskih sukoba dogode u određenom turističkom području, tada su turizam, turisti i lokalno gospodarstvo uvijek pod utjecajem tih incidenata (Metodijeski i Filiposki, 2016).

Odsustvo osjećaja sigurnosti stvara osjećaj nesigurnosti, a percipira se u obliku određenog rizika, često temeljenog na informacijama iz medija (Adeloyea i Browna, 2018). Apsolutni ili realni rizik je vjerojatnost pojave određenih nepovoljnih događaja umnožena opsegom njihovih posljedica, a subjektivni ili percipirani rizik je intuitivna individualna percepcija tih čimbenika (Larsen i dr., 2009:260). Često je subjektivni rizik veći od realnoga. Primjerice, vjerojatnost od automobilske nesreće statistički je veća od vjerojatnosti zrakoplovne nesreće. Ipak, potonji je rizik percipiran većim za putnike koji izbjegavaju putovati zrakoplovom. Također, vrlo je rijetko da potrošači zaista znaju vjerojatnost stvarnog rizika (Reisinger i Mavondo, 2006:14). Rizici u turizmu mogu se pojaviti unutar brojnih područja. Reisinger i Mavondo (2006) definirali su rizik u turizmu kao rizik percipiran ili doživljen za vrijeme procesa kupnje i konzumiranja turističkih usluga te, uzimajući u obzir postojeću literaturu, ističu pet glavnih rizika vezanih uz turizam: terorizam, rat i politička nestabilnost, zdravstveni rizici, kriminal te kulturalne i jezične poteškoće.

Terorizam je nazvan primarnom prijetnjom sigurnosti 21. stoljeća, stoga je na vrhuncu masovnosti svjetskog turizma narastao i rizik od uključenosti u teroristički napad (Hall, 2010). Prema mnogim autorima, terorizam je najveća prijetnja međunarodnom turizmu s potencijalno puno većim negativnim učinkom po turizam od bilo koje druge katastrofe ili nesreće uzrokovane s ljudske strane ili pak prirode (Reisinger i Mavondo, 2006:14). Razlika između terorizma prije nekoliko desetljeća i suvremenog terorizma leži u tome što je suvremeni terorizam obilježen napadima koji se civilima čine slučajnima ili nasumičnima, dok nacionalni terorizam ima obilježje sistematičnosti. Naime, sistematični terorizam obično je usmjeren na točno određene žrtve (Korstanje, 2012:9). Neizravan kontakt s terorizmom može biti osjećaj pojedinca da je izbjegao napad zahvaljujući sreći ako se netom prije napada nalazio na istom mjestu, sudjelovanje u bilo kojem obliku pomoći ili poznavanje osoba koje su doživjele teroristički napad u prošlosti (Seabra i dr, 2014:878).

Prema Global Peace Index Reportu 2018 utjecaj terorizma izračunat je za 163 zemlje temeljem 23 kvalitativna i kvantitativna indikatora, a rezultat je pokazao ukupno pogoršanje. Desetogodišnji trend miroljubivosti na globalnoj razini pogoršan je za 2,38 \%, gdje 85 zemalja bilježi pogoršanje, dok se u 75 zemalja stanje poboljšalo (IEP, 2018:2).

\section{2 Percepcija sigurnosti kao kriterij pri odabiru destinacije}

Osobna sigurnost tijekom putovanja glavni je motivacijski atribut u privlačenju turista u određenu turističku destinaciju (Hua i Yoo, 2011). Destinacije koje turisti smatraju nesigurnima ne smatraju se privlačnima pri izboru destinacije za odmor (Mansfeld i Pizam, 2006) i jasno je da pojava nasilja ima snažan negativni utjecaj na odabir destinacije. Turisti će prilikom odabira destinacije biti pod utjecajem informacija o sigurnosti iz medija, no oni će dolaskom u destinaciju imati vlastito iskustvo o sigurnosnim uvjetima u toj destinaciji. Učinci te percepcije sigurnosti doživljene tijekom posjeta nedovoljno su istražene (Adeloyea i Browna, 2018). Osiguravanje posjetiteljima da se osjećaju 
sigurno prijeiza vrijeme svog boravka može biti ključno za postizanje međunarodne konkurentnosti destinacije, budući da turisti prilikom planiranja svog putovanja često razmatraju više potencijalnih mogućnosti (Kozak i Crotts, 2007:234). Za uspješno pozicioniranje turističkih destinacija i nositelja ponude u destinacijama nameće se potreba za razumijevanjem kako potencijalni turisti percipiraju koncept rizika i sigurnosti u turizmu, a percepcija rizika vrlo je subjektivna i individualna stavka u mentalnom sklopu pojedinaca. (Ling Yang i Nair, 2014:323). Ako se proces donošenja odluke o putovanju, kao i odabira destinacije, shvati kao proces koji se sastoji od više faza u kojima do izražaja prvenstveno dolaze psihološki faktori, tada se sigurnost može razmatrati kao sastavni dio jedne od prvih faza tog procesa (Senečić i Grgona, 2006:16).

Percipirano i stvarno stanje sigurnosti ne moraju biti u skladu jedno $s$ drugim. No, ako je stvarno sigurnosno stanje ugroženo ili narušeno te su informacije o tome medijski i usmenom komunikacijom raširene, percipirana će se sigurnost najčešće oblikovati prema dostupnim informacijama. Stoga postoji opasnost od veće razine percipiranog rizika od stvarnog (Santana 2004:304). Percepcija rizika je vizija utemeljena na vjerojatnosti pojave negativnih posljedica koje proizlaze iz odluka ili ponašanja turista (Morakabati, 2007:181). Tijekom procesa donošenja odluke o putovanju potencijalnog turista, visoko percipirani rizik i zabrinutosti vezane uz sigurnost postali su središnje pitanje. Do sada se pokazalo kako upitna sigurnost može spriječiti putovanja u određene destinacije (Kozak i dr, 2007:233). Percipirani rizik i manjak sigurnosti izravno utječu na izbjegavanje rizičnih regija. Destinacije koje su percipirane kao prerizične mogu biti eliminirane s popisa potencijalnih destinacija za posjet (Reisinger i Mavondo, 2006:17). Osim utjecaja na turističke tokove, percepcija nestabilnosti može uzrokovati i dugoročne posljedice na razvoj turizma smanjenjem vjerojatnosti domaćeg $i$ inozemnog ulaganja u turističku infrastrukturu $i$ povećanjem troškova osiguranja takvih ulaganja (Seddighi i dr., 2001:182).

Prema Ribeiro i dr. (2018) percipirana sigurnost utječe na lojalnost turista jer, ako se oni osjećaju nesigurno u destinaciji, nemaju se namjeru vraćati. $U$ nekoliko studija (Chew i Jahari, 2014; Artuger, 2015; Sohn, Lee i Yoon, 2016) istraživan je učinak percepcije rizika na namjeru ponovnog posjeta turističke destinacije. Istraživanja su dokazala postojanje izravne povezanosti između percepcije, zadovoljstva i budućih namjera dolaska. Sprječavanje pojave krize, u mjeri u kojoj je moguće, adekvatno reagiranje na krizu i odgovor na krizna zbivanja radi što bržeg oporavka, nužna su postupanja i na državnoj, ali i na lokalnoj destinacijskoj razini u okviru upravljanja krizom (Althnayan, 2012:25). Osim uspostave temelja za krizni menadžment, konstantno ulaganje u održavanje i povećanje razine sigurnosti u svim njenim segmentima od izuzetne je važnosti. Istraživanje Bowena i drugih (2014) o percepciji rizika i sigurnosti turista na kruzerima, pokazalo je kako većina ispitanika (81 \%), unatoč tome što se slažu s tvrdnjom o postojanju visoke razine sigurnosti u kruzing-turizmu, poboljšanje mjera sigurnosti smatraju pozitivnim te na svaki pokušaj povećanja razine sigurnosti u kruzing-turizmu gledaju s odobravanjem (Bowen i dr, 2014:622).

\section{METODOLOGIJA}

Empirijsko istraživanje provedeno je on-line upitnikom kreiranim korištenjem Google Docs obrasca, na uzorku od 101 ispitanika, Erasmus studenata i njihovih kolega u periodu od 1. do 30. travnja 2017. godine. Sudjelovanje u istraživanju bilo je u potpunosti anonimno i dobrovoljno. 
Istraživanjem se nastojao steći uvid u percepciju ispitane mlade populacije o stanju sigurnosti u smislu vjerojatnosti pojave određenih rizika u 8 različitih zemalja, među kojima je i Hrvatska, te tako smjestiti Hrvatsku na percepcijsku sliku sigurnosti u usporedbi s ostalim konkurentskim zemljama. $U$ uvodnom dijelu anketnog upitnika ispitanicima je naglašeno kako se za potrebe ovog istraživanja pod rizikom podrazumijevaju prvenstveno opasnosti uzrokovane ljudskim djelovanjem, od kojih su u fokusu opasnost od terorizma, ratova te političkih nestabilnosti. Prema Strategiji razvoja turizma Republike Hrvatske do 2020., u konkurentski krug mediteranskih zemalja pripadaju Španjolska, Francuska, Italija, Grčka i Turska. Stoga su upravo te zemlje uvrštene u istraživanje kako bi se Hrvatsku moglo usporediti sa zemljama užeg konkurentskog okruženja.

$\mathrm{U}$ prvom dijelu anketnog upitnika ispitanike se propitivalo o njihovom iskustvu putovanja u inozemstvo, željiza putovanjem, o tomejesuli ikada posjetili Hrvatskuteo motivacijiza poduzimanje putovanja i važnosti određenih elemenata prilikom odabira destinacije. Pri sastavljanju upitnika korišteni su segmenti dvaju prethodnih istraživanja o motivacijskim čimbenicima i turističkom ponašanju mladih (Bicikova, 2014; Richards i Wilson, 2003). Interakcija s lokalnim stanovništvom, povećanje znanja i „pronalaženje sebe“ korišteni su iz istraživanja o mladim putnicima (Richards i Wilson, 2003). Ostali elementi, poput druženja s prijateljima, istraživanje novih mjesta i kultura, izbjegavanje svakodnevnice i interakcija s lokalnim stanovništvom, noćni život i izlasci te sport preuzeti su iz istraživanja o turističkim navikama studenata (Bicikova, 2014).

Glavni dio anketnog upitnika činila je matrica s mogućnošću ocjene svakog od navedenih pet elemenata rizika (Reisinger i Mavondo, 2006; Kozak, 2007) prema vjerojatnosti njegove pojave u svakoj od osam ispitanih zemalja. Nakon toga ispitivani su stavovi o tvrdnjama vezanim za osjećaj sigurnosti, osobnu percepciju rizika i turističko ponašanje u uvjetima rizika. Anketa je završila pitanjima o sociodemografskim obilježjima ispitanika. Od sto i jedne osobe koje su pristupile ispunjavanju anketnog upitnika, šesnaestoro je upitnik ispunilo nepotpuno, odnosno polovično te su takve ankete odbačene. Dakle, ukupno je obrađeno 85 anketnih upitnika.

\section{1 Uzorak}

Uzorak na kojemu je anketiranje provedeno bili su stranci, odnosno osobe koje nisu hrvatski državljani, niti žive u Hrvatskoj te su u Hrvatskoj bile kao posjetitelji ili je nikada nisu posjetili. Dostupan uzorak većinom su mlađe osobe i studenti. Zemlje u kojima ispitanici žive su sljedeće: Njemačka, Turska, Francuska, Poljska, Ujedinjeno Kraljevstvo, Portugal, Nizozemska, Slovenija, Austrija, Švicarska, Latvija, Finska, Belgija, Bugarska, Danska, Indija, Kenija, Rumunjska, Slovačka, SAD i Ukrajina. 
Tablica 1. Sociodemografska obilježja ispitanika

\begin{tabular}{|c|c|c|c|}
\hline $\begin{array}{c}\text { SOCIODEMOGRAFSKE } \\
\text { VARIJABLE }\end{array}$ & OBILJEŽJA & FREKVENCIJA & $\%$ \\
\hline \multirow[t]{2}{*}{ Spol } & Muški & 30 & 35,3 \\
\hline & Ženski & 55 & 64,7 \\
\hline \multirow[t]{3}{*}{ Dob } & $18-24$ & 53 & 62,4 \\
\hline & $25-29$ & 26 & 30,6 \\
\hline & $30<$ & 6 & 7,1 \\
\hline \multirow[t]{4}{*}{ Razina obrazovanja } & srednja stručna sprema ili niže & 7 & 8,2 \\
\hline & viša škola ili prvostupnik & 52 & 61.2 \\
\hline & fakultet ili magistar struke & 17 & 20,0 \\
\hline & znanstveni magisterij ili doktorat & 9 & 10,6 \\
\hline \multirow[t]{4}{*}{ Status } & učenik/ica, student/ica & 59 & 69,4 \\
\hline & zaposlen/a & 23 & 27,1 \\
\hline & nezaposlen/a & 1 & 1,2 \\
\hline & ostalo & 2 & 2,4 \\
\hline \multirow[t]{3}{*}{ Bračni status } & neudata/neoženjen & 75 & 88,2 \\
\hline & udata/oženjen ili partnerstvo & 8 & 9,4 \\
\hline & ostalo & 2 & 2,4 \\
\hline \multirow[t]{4}{*}{ Mjesečni prihod u EUR } & do 500 & 32 & 37,7 \\
\hline & od 501 do 1000 & 30 & 35,3 \\
\hline & od 1001 do 2000 & 21 & 24,7 \\
\hline & više od 2000 & 2 & 2,4 \\
\hline \multirow[t]{2}{*}{$\begin{array}{c}\text { Iskustvo međunarodnog } \\
\text { putovanja }\end{array}$} & $\mathrm{Da}$ & 82 & 96,5 \\
\hline & $\mathrm{Ne}$ & 3 & 3,5 \\
\hline
\end{tabular}

Izvor: rezultati istraživanja

Od 85 ispitanika obuhvaćenih istraživanjem, većina su ženskog spola (64,7\%). Najzastupljenija dobna skupina u ukupnom uzorku ujedno je i najmlađa, odnosno skupina od 18 do 24 godine koja 
čini natpolovičnu većinu (62,4\%). Prosječna dob ispitanika je 25 godina. Najveći broj ispitanika čine osobe $s$ razinom obrazovanja više škole ili prvostupnika $(61,2 \%)$, a slijedi razina fakulteta i magistra struke (20,0 \%). Većina ispitanika su studenti, neudate i neoženjene osobe (88,2\%), a prosječni mjesečni prihod je do 2000 eura. Gotovo svi ispitanici (96,5\%) imaju iskustvo putovanja u inozemstvo, dakle turistički su putovali izvan granica zemlje u kojoj žive. Uzevši u obzir kako većina ispitanika pripada mlađoj populaciji, podaci o iskustvu inozemnog putovanja i želje za putovanjem potvrđuju vrlo istaknutu prisutnost „trenda putovanja“ kod mladih. Putovanje mladih i studenata postaje jedan od najbrže rastućih segmenata međunarodnog turizma, predstavljajući više od $23 \%$ od preko milijardu međunarodnih turista koji putuju svake godine (UNWTO, 2016:5). Dugoročno gledajući, putovanja mladih danas čine osnovu za turističke odluke budućih generacija, stoga su potrebe, preferencije i percepcija ovog segmenta turista vrijedne proučavanja.

\section{REZULTATII DISKUSIJA}

Prema istraživanju Bickove (2014) posebno su istaknuti faktori privlačenja, definirani kao materijalni i nematerijalni resursi imidža određene destinacije koji omogućavaju realiziranje potreba. Rezultati ovog istraživanja, prikazani u tablici 2, pokazali su kako je cijena najutjecajniji pull faktor među mladim turistima, što se, ako se uzme u obzir kako je gotovo 70 \% ispitanika u ovom istraživanju studentska populacija, slaže s rezultatima prethodno spomenutog istraživanja gdje je zaključeno kako je niska cijena putovanja najutjecajniji pull faktor na studentskom turističkom tržištu.

Tablica 2. Važnost pojedinih kriterija pri odabiru destinacije

\begin{tabular}{|cc|}
\hline Kriteriji & Prosječna vrijednost \\
\hline Cijena putovanja & 4,00 \\
\hline Sigurnost (terorizam, nestabilnost) & 3,95 \\
\hline Klima & 3,76 \\
\hline Dostupnost destinacije & 3,75 \\
\hline Čistoća & 3,49 \\
\hline Turističke atrakcije & 3,20 \\
\hline Raznolikost zabave i događanja & 3,20 \\
\hline Popularnost destinacije & 2,73 \\
\hline
\end{tabular}

Izvor: rezultati istraživanja

Rezultati istraživanja pokazali su kako je upravo sigurnost sljedeći najvažniji kriterij (3,95), Naime, sigurnost je element ocijenjen značajno većom ocjenom od elemenata poput raznolikosti zabave i popularnosti destinacije, čime se potvrđuje da je turistima sigurnost bitan faktor pri odabiru destinacije. 
U nastavku istraživanja slijedi analiza matrice s ocjenama pet elemenata rizika prema vjerojatnosti njegove pojave u svakoj od osam ispitanih zemalja. Ispitanici su navedene rizike ocjenjivali ocjenom od 1 do 5, pri čemu je pojava rizika mogla biti od 1 - „vrlo niska“, do 5 - „vrlo visoka“. Navedeni elementi rizika su sljedeći:

1) Unutarnje političke napetosti ili sukobi

2) migrantska kriza

3) izbijanje sukoba

4) društveni ili politički nemiri

5) opasnost od terorističkog napada.

Cilj ovog dijela upitnika bio je ispitati percepciju ispitanika vezanu uz jačinu različitih rizika uzrokovanih ljudskim djelovanjem, u različitim zemljama. Pretpostavlja se kako postojanje navedenih rizika djeluju odbojno na potencijalnog turista. Zemlje koje su ispitanici ocjenjivali su sljedeće: Hrvatska, Španjolska, Francuska, Italija, Grčka, Turska, Njemačka te Bosna i Hercegovina. Ispitanici su uz svaku zemlju u tablici naznačili jednu od tri mogućnosti; da žive u toj zemlji, da su posjetili tu zemlju ili niti jedno niti drugo, kako bi se utvrdilo postoje li razlike u rezultatima među ispitanicima iz navedene tri kategorije, Na grafikonu 1 prikazani su rezultati za vjerojatnost pojave rizika u Hrvatskoj.

\section{Grafikon 1. Percepcija rizika za Hrvatsku}

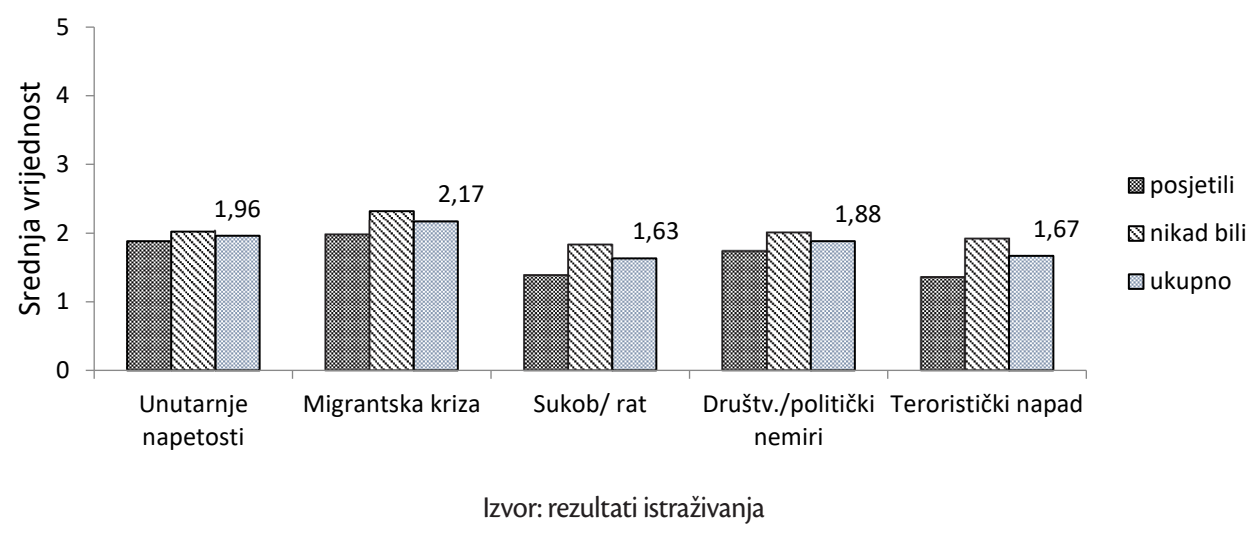

Na grafikonu 1 koji prikazuje rezultate istraživanja za Hrvatsku migrantska kriza percipirana je kao najvjerojatniji rizik (2,17). Srednje vrijednosti vjerojatnosti pojave svih ostalih rizika niže su od 2,00. Slijedi vjerojatnost pojave unutarnje političkih napetosti $(1,96)$, društvenih ili političkih nemira $(1,88)$, terorističkog napada $(1,67)$ te eskalacija sukoba ili rata $(1,63)$. Zanimljivo je kako su ispitanici koji su bili u Hrvatskoj nižim ocjenama vrednovali vjerojatnost pojave navedenih rizika, u odnosu na ispitanike koji nisu posjetili Hrvatsku. Standardna devijacija se kreće između 0,77 i 1,02. U rezultatima za Hrvatsku i Španjolsku uočena je najniža razina varijacije u standardnim devijacijama. 
Radi sveobuhvatnog pregleda, slijedi prikaz svih rezultata za svih osam zemalja na linijskom grafikonu. Na apscisi se nalaze brojevi od 1 do 5 , a predstavljaju rizike, prema istom redoslijedu kao i na prethodnim grafikonima.

Grafikon 2. Sumarni prikaz rezultata percepcije rizika prema zemljama

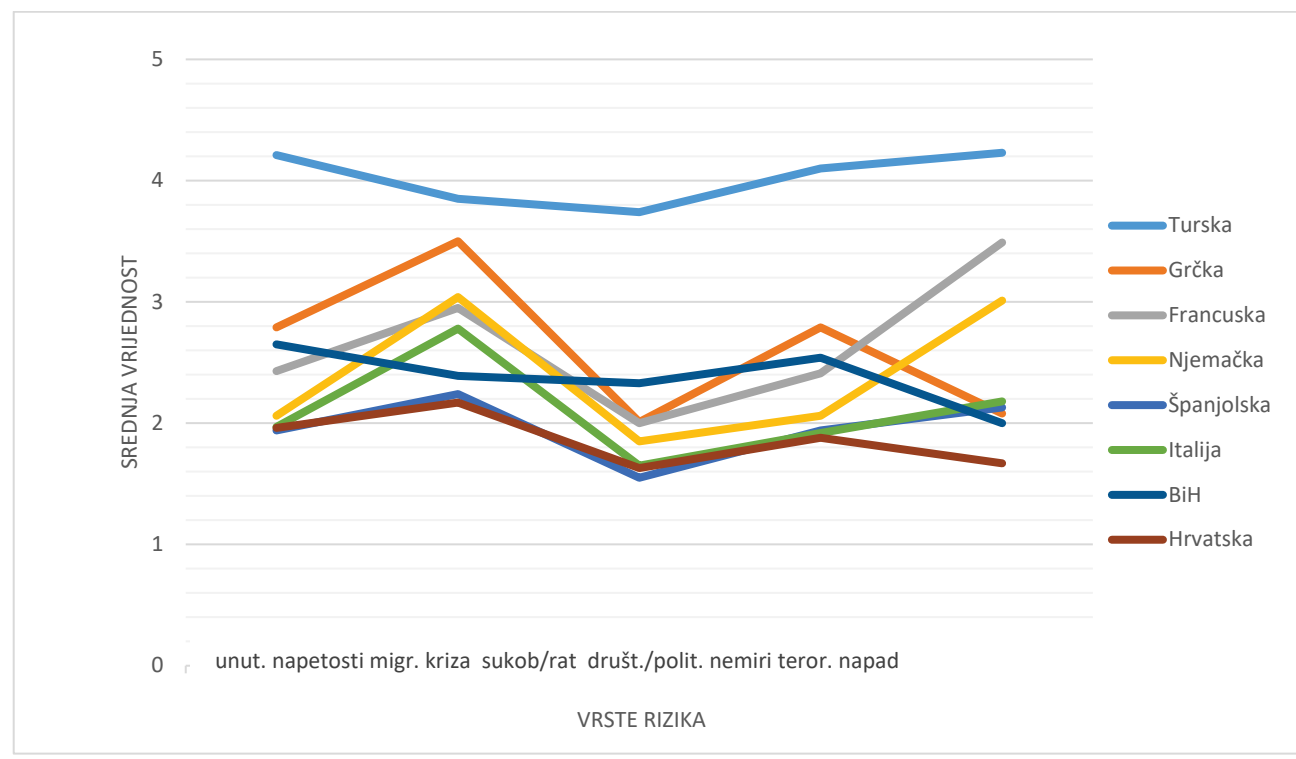

Izvor: rezultati istraživanja

Na grafikonu 2 najočitije se izdvaja linija koja označava Tursku i koja je prema svim segmentima rizika ocijenjena najvećim vrijednostima. Nasuprot Turskoj, najdonja linija predstavlja Hrvatsku, koja je prema rezultatima istraživanja, od pet ocjenjivanih elemenata, $u$ tri elementa ocijenjena s najmanjom vrijednošću.

Prvi rizik prema redoslijedu na apscisi jest rizik od unutarnjih političkih napetosti ili sukoba, što uključuje političku nestabilnost, ograničenje demokracije, gušenje sloboda i slično. Nakon Turske $(4,21)$, čija se vrijednosna linija nalazi daleko iznad ostalih zemalja, slijede Grčka $(2,79)$, Bosna i Hercegovina $(2,65)$ i Francuska $(2,43)$. Drugi rizik podrazumijeva izbijanje migrantske krize. Kao i kod ocjene prethodnog rizika, predvodi Turska (3,85), a slijedi Grčka (3,50). Najbliže dnu su linije Španjolske $(2,24)$ i Hrvatske $(2,17)$. Treći rizik je rizik od izbijanja sukoba ili ratnih eskalacija, čija je vjerojatnost pojave ukupno ocijenjena najnižom ocjenom. Na grafikonu je u ovom segmentu vidljiv najveći raskorak između linije Turske i ostalih zemalja. Četvrti rizik na grafikonu 2 predstavlja vjerojatnost pojave društvenih ili političkih nemira. Nakon Turske $(4,10)$, slijede redom Grčka $(2,79)$, Bosna i Hercegovina (2,54), Francuska (2,41) i Njemačka (2,06). Značajno je usmjeriti pozornost na desne krajeve linija, gdje se nalaze vrijednosti percipirane vjerojatnosti od terorističkog napada, a gdje se linija Hrvatske nalazi na uvjerljivo najnižoj razini $(1,67)$. Hrvatska je jedina zemlja ocijenjena ocjenom manjom od 2,00. 
Na temelju rezultata može se zaključiti kako postoji razlika u vjerojatnosti pojave određenih rizika u različitim zemljama iz perspektive ispitanika, potencijalnih turista, te kako postoje čak i značajnije razlike u percepciji zemalja unutar istog konkurentskog okruženja. Također, primijećena je razlika između percipiranja rizika između ispitanika koji su bili u zemlji čiju pojavu rizika procjenjuju i ispitanika koji tu zemlju nisu posjetili, što se slaže s rezultatima prethodnih istraživanja koja potvrđuju kako osobno iskustvo reducira percipirani rizik. Razlika je vidljiva i kod percepcije ispitanika o pojavi rizika u zemlji u kojoj žive, u usporedbi s ostalim ispitanicima kojima je ta zemlja strana. Stoga se za daljnja istraživanja predlaže i detaljnije istraživanje percepcije rizika turista u destinacijama, uzevši u obzir njihovo osobno iskustvo, što je zaključeno i u istraživanju Adeloyea i Browna (2018).

Od svih uzroka nesigurnosti nastalih ljudskim djelovanjem, u ovome je radu naglasak stavljen na terorizam, kao jednom od trenutno najvidljivijih destruktivnih faktora po globalnu sigurnost. Svakodnevna događanja u svijetu upućuju na to kako nesigurnosti na globalnoj razini nemaju tendenciju smanjenja ili nestanka. $U$ takvim okolnostima sigurnost je kriterij koji postaje sve bitniji potencijalnim turistima, pa sigurnost destinacije postaje značajna konkurentska prednost.

\section{ZAKLJUČAK I PREPORUKE}

Nesigurnost je oduvijek bila primarni neprijatelj turizmu, iako rastuća razina globalne nesigurnosti neće zaustaviti progresivni razvoj turizma. U Strategiji razvoja turizma Republike Hrvatske do 2020. godine, sigurnost je navedena kao jedan od čimbenika kojima bi Hrvatska mogla privlačiti turističku potražnju te je navedeno kako je „osjećaj sigurnosti“ u Hrvatskoj ocijenjen boljim u odnosu na konkurentske zemlje Mediterana, što je potvrđeno i istraživanjem u ovom radu. Hrvatska je generalno pozitivno percipirana kao destinacija, kako po pitanju atraktivnosti destinacije, tako i po pitanju sigurnosti.

Hrvatska je, iz perspektive ispitanika koji su pretežito mlade osobe sklone međunarodnom putovanju, a koji su sigurnost ocijenili jednim od najvažnijim kriterijima pri odabiru destinacije, percipirana kao zemlja niže vjerojatnosti pojave rizika na globalnoj razini te kao vrlo sigurna destinacija. Promatrajući dugoročno, putovanja mladih danas osnova su turističkih odluka budućnosti, stoga su njihove preferencije i percepcije vrijedne daljnjeg analiziranja. $U$ tom se kontekstu Hrvatska, koristeći pozitivnu percepciju o sigurnosti, može uspješno pozicionirati.

Ograničenja provedenog istraživanja očituju se prvenstveno u veličini uzorka i u relativno kratkom vremenu provođenja te ograničenosti financijskih sredstava. Daljnja istraživanja u ovom području svakako će biti potrebna, s obzirom na nedovoljnu istraženost i rastuću potrebu za razumijevanjem ponašanja turista te veće osviještenosti o osobnoj sigurnosti pod utjecajem rapidnih promjena u društvu.

Iz navedenih ograničenja proizlaze preporuke za daljnja istraživanja, bilo onih usmjerenih na temu percepcije rizika pojedinih zemalja i potencijalnom ponašanju turista u uvjetima percipirane nesigurnosti ili pak fokusirajući se na percepciju Hrvatske kao destinacije u kontekstu sigurnosti. Budući da se većim dijelom radi o ispitivanju osjećaja i percepcije, potrebno je voditi računa o tome da trenutak ispitivanja može utjecati na rezultate, stoga bi bilo poželjno izbjeći provođenje 
istraživanja neposredno nakon većih događaja koji su narušili sigurnost, a imali su velik odjek u medijima, ili, pak, usporediti rezultate ispitivanja provedene u vremenu neposredno nakon takvih događaja s onima dobivenih $u$ „mirnijem“ razdoblju. Budući da je istraživanje pokazalo kako se pri ocjenjivanju rizičnosti zemalja razlikuju odgovori lokalnog stanovništva i stranaca, ali i kako je standardna devijacija vrlo visoka u određenim slučajevima kod odgovora rezidenata, valjalo bi također pri ispitivanju percepcije rizika segmentirati ispitanike ovisno o tome gdje žive te žive li u urbanim ili ruralnim sredinama. Obuhvaćanje stila života, vrste osobnosti i kulturološke pozadine ispitanika također bi moglo dati zanimljive rezultate. Bilo bi poželjno provesti detaljnije i obuhvatnije istraživanje na većem reprezentativnom uzorku, heterogenijoj dobnoj skupini i tijekom duljeg vremenskog razdoblja.

\section{LITERATURA}

Adeloye, D., Brown, L. (2018) “Terrorism and domestic tourist risk perceptions" Journal of Tourism and Cultural Change, 16, p. 217-233 https://doi.org/10.1080/14766825.2017.1304399

Althnayan A. (2012) Tourism and terrorism: A crisis management perspective - An investigation of stakeholders' engagement in the context of Egyptian holiday destinations, University of Hull

Artuger, S. (2015) “The Effect of Risk Perceptions on Tourists' Revisit Intentions" European Journal of Business and Management 7(2), p. 36-43

Bicikova, K. (2014) “Understanding Student Travel Behavior: A Segmentation Analysis of British University Students", Journal of Travel \& Tourism Marketing, 31(7), p. 854-867. https://doi.org/10.1080/10548408.2014.890154

Bowen C., Fidgeon P., Page S. J. (2014) "Maritime tourism and terrorism: customer perceptions of the potential terrorist threat to cruise shipping", Current Issues in Tourism, 17(7), p. 610-639. https://doi.org/10.1080/13683500.2012.743 973

Chew, E. Y. T., Jahari, S. A. (2014) "Destination Image as a Mediator between Perceived Risks and Revisit Intention: A Case of Post-disaster Japan." Tourism Management, 40, p. 382-393. https://doi.org/10.1016/j.tourman.2013.07.008

Hall, C. M. (2010) "Crisis events in tourism: subjects of crisis in tourism", Current Issues in Tourism, 13(5), p. 401-417. https://doi.org/10.1080/13683500.2010.491900

Hua, Y., Yoo, J. J. (2011) "Travel motivations of Mainland Chinese travelers to the United States" Journal of China Tourism Research, 7(4), p. 355-376. https://doi.org/10.1080/19388160.2011.627000

Korstanje M. E., Clayton A. (2012) "Tourism and terrorism: conflicts and commonalities", Worldwide Hospitality and Tourism Themes, 4(1), p. 8-25. https://doi.org/10.1108/17554211211198552

Kozak, M., Crotts, J. C. (2007) "The Impact of the Perception of Risk on International Travellers", International Journal of Tourism Research, 9(4), p. 233-242. https://doi.org/10.1002/jtr.607

Larsen, S., Brun, W., Ogaard, T.(2009) "What tourists worry about - Construction of a scale measuring tourist worries", Tourism Management, 30, p. 260-265. https://doi.org/10.1016/j.tourman.2008.06.004

Ling Yang, C., Nair, V. (2014) “Risk perception study in tourism: Are we really measuring percieved risk?", Procedia Social and Behavioral Sciences, 144, p. 322-327. https://doi.org/10.1016/j.sbspro.2014.07.302

Mansfeld, Y., Pizam, A. (2006) "Toward a theory of tourism security. In Tourism, Security and Safety: From Theory to Practice", Mansfeld, Y., Pizam, A., Eds.; Elsevier, Butterworth-Heinemann: Burlington, MA, USA, p. 1-28. https://doi. org/10.1016/B978-0-7506-7898-8.50004-7

Maslow, A. (1954) Motivation and Personality, Harper, New York 


\section{Bagarić, M. Barišić, L. Martić Kuran: Značaj percepcije osobne sigurnosti u turističkoj destinaciji...}

Zbornik Veleučilišta u Rijeci, Vol. 7 (2019), No. 1, pp. 209-221

Metodijeski, D., Filiposki, O. (2016) Tourism policy and security: the case of terrorism, Institute for Socio-Cultural Anthropology of Macedoniam, University Goce Delchev

Morakabati Y. (2007) Tourism, travel risk and travel risk perceptions: a study of travel risk perceptions and the effects of incidents on tourism, Bournemouth University

Reisinger, Y., Mavondo, F. (2006) “Cultural Differences in Travel Risk Perception”, Journal of Travel \& Tourism Marketing, 20(1), p. 13-31. https://doi.org/10.1300/J073v20n01_02

Ribeiro, M. A. et al. (2018) “Tourists' Destination Loyalty through Emotional Solidarity with Residents: An Integrative Moderated Mediation Model" Journal of Travel Research 57(3), p. 279-95. https://doi. org/10.1177/0047287517699089

Richards, G., Wilson, J. (2003) Today's Youth Travellers: Tomorrow's Global Nomads. New Horizons in Independent Youth and Student Travel, International Student Travel Confederation (ISTC)

Santana G. (2004) “Crisis Management and Tourism", Journal of Travel \& Tourism Marketing, 15(4), p. 299-321. https:// doi.org/10.1300/J073v15n04_05

Seabra C., Abrantes J. L., Kastenholz E. (2014) "The influence of terrorism risk perception on purchase involvement and safety concern of international travellers", Journal of Marketing Management, 30(9-10), p. 874-903. https://doi.org/ 10.1080/0267257X.2014.934904

Seddighi, H. R., Nuttall, M. W., Theocharous, A. L. (2001) “Does cultural background of tourists influence the destination choice? An empirical study with special reference to political instability", Tourism Management, 22, p. 181-191. https://doi.org/10.1016/S0261-5177(00)00046-7

Senečić, J., Grgona, J. (2006) Marketing menadžment u turizmu, Mikrorad d. o. o., Zagreb

Sirakaya, E., Sheppard A. G., McLellan, R. W. (1997) "Assessment of the relationship between perceived safety at a vacation site and destination choice decisions: extending the behavioral decision-making model", Journal of Hospitality \& Tourism Research, 21(2), p. 1-10. https://doi.org/10.1177/109634809702100201

Sohn, H. K., Lee, T. J., Yoon, Y. S. (2016) “Relationship between Perceived Risk, Evaluation, Satisfaction, and Behavioral Intention: A Case of Local-Festival Visitors." Journal of Travel \& Tourism Marketing 33 (1), p. 28-45. https://doi.org/1 0.1080/10548408.2015.1024912

Young-Sun Shin (2005) "Safety, security and peace tourism: The case of the DMZ area", Asia Pacific Journal of Tourism Research, 10(4), p. 411-426. https://doi.org/10.1080/10941660500363777

Yu, L., Chung, M. H. (2001) “Tourism as a Catalytic Force for LowPolitics Activities between Politically Divided Countries:The Cases of South/North Korea and Taiwan/China", New Political Science, 23(4), p. 537-545. https://doi. org/10.1080/07393140120099624

Institute for Economics \& Peace (2018) Global Peace Index, http://visionofhumanity.org/app/uploads/2018/06/GlobalPeace-Index-2018-2.pdf, pristup 10. 1. 2019.

UNWTO World Tourism Organization (2017) Annual report. https://www.e-unwto.org/doi/ book/10.18111/9789284419807, pristup 6. 9. 2018.

UNWTO World Tourism Organisation (2016) Global Report on The Power of Youth Travel. http://cf.cdn.unwto.org/ sites/all/files/pdf/wyse_powerofyouthtravel.pdf, pristup 15. 9. 2018. 


\title{
THE IMPORTANCE OF PERSONAL SAFETY PERCEPTION IN A TOURIST DESTINATION FROM THE PERSPECTIVE OF YOUNG TOURISTS
}

\author{
Lidija Bagarić \\ PhD, Assistant Professor, University of Rijeka, Faculty of Tourism and Hospitality Management, \\ Primorska 42, p.p. 97, 51410 Opatija, Croatia; e-mail: lidijab@ fthm.hr
}

Mateja Barišić

MA in Economics, Student, University of Rijeka, Faculty of Tourism and Hospitality Management, Primorska 42, p.p. 97, 51410 Opatija, Croatia; e-mail:ds2427@fthm.hr

Linda Martić Kuran

Univ. spec. oec., Senior Lecturer, Polytechnic Marko Marulić in Knin, Petra Krešimira IV 30, Knin, Croatia; e-mail:Imartic@veleknin.hr

\begin{abstract}
Contemporary tourism contributes to the recognition and convergence of different cultures through the development of transport and various forms of communication and other technologies. Tourism increases mutual tolerance and contributes to world peace, while significant preconditions for tourism development are destination peace and safety at the same time. Tourism development is in the interest of many countries due to its positive and multiplier impact on the economy, but there are also major changes in the safety aspect of countries around the world, thus safety becomes one of the most important elements in choosing destinations. Consequently, tourist behaviour patterns change, and the personal safety of tourists, resulting from the safety situation in the country, becomes an increasingly important element for successful positioning of tourist destinations. The aim of this paper is to present the attitudes of young foreign tourists about the safety of the destination and their perception of the safety situation in Croatia in regards to competitive countries. The research results show that safety perception is a significant element when choosing a destination to travel, and Croatia is perceived as above-average safe country, which are important data that should be used more in promoting Croatia as a tourist destination.
\end{abstract}

Key words: personal safety, global insecurity, terrorism, risk perception 